\title{
Composition of the essential oil and micromorphology of trichomes of Teucrium salviastrum, an endemic species from Portugal
}

\author{
Carlos Cavaleiro, ${ }^{1}$ Ligia R. Salgueiro, ${ }^{1 *}$ Teresa Antunes, ${ }^{2}$ Isabel Sevinate-Pinto ${ }^{2}$ and José G. Barroso ${ }^{3}$ \\ 1 Laboratório de Farmacognosia/CEF, Faculdade de Farmácia, Universidade de Coimbra, Rua do Norte, 3000 Coimbra, Portugal \\ 2 Centro de Biologia Ambiental, Departamento de Biologia Vegetal, Faculdade de Ciências de Lisboa, C2, Campo Grande 1700, \\ Lisboa, Portugal \\ ${ }^{3}$ Centro de Biotecnologia Vegetal, Departamento de Biologia Vegetal, Faculdade de Ciências de Lisboa, C2, Campo Grande 1700, \\ Lisboa, Portugal
}

Received 5 July 2001

Revised 28 November 2001

Accepted 30 November 2001

\begin{abstract}
The morphology, distribution and release mechanism of the glandular trichomes of Teucrium salviastrum Schreber were studied, along with the chemical composition of the essential oils. Peltate and capitate trichomes are present on both vegetative and reproductive organs. In this study, particular emphasis is given to the capitate trichomes with long multicellular stalks. These trichomes are very abundant, and the secretion material is released by cuticule rupture on the top of the head cells. Also noteworthy is the presence of peltate trichomes on the upper surface of the ovary. Although already described in some Lamiaceae, these trichomes have not been recorded previously on any other Teucrium species. The composition of the essential oil was studied using mainly GC and GC-MS. The oils isolated from leaves, collected during the flowering and post-flowering phases of the plant, as well as the oil isolated from the flower heads, exhibited a similar chemical composition. Nevertheless, the oils showed remarkable differences in composition when compared to those reported in the literature for the same species. The present study has shown that our oil consisted mainly of $E$ - $\beta$-farnesene (26.1-29.3\%), E-caryophyllene (19.1-24.1\%) and germacrene D (13.7-21.6\%). The major compound of our samples, $E$ - $\beta$-farnesene, is reported for the first time for this species. Copyright (C) 2002 John Wiley \& Sons, Ltd.
\end{abstract}

KEY WORDS: Teucrium salviastrum; endemic species; trichomes; histochemistry; essential oils; GC; GC-MS

\section{Introduction}

Teucrium salviastrum Schreber (Lamiaceae) is an endemic species from the highlands of the centre and north of Portugal, with a distribution almost always restricted to areas above $1000 \mathrm{~m}$. It is a dwarf shrub up to $30 \mathrm{~cm}$, with petiolate, entire, ovate-oblong or elliptic leaves. The calyx is bilabiate, strongly veined, glandular and villous. The purplish corolla is bilabiate and villous with shortly exerted stamens. ${ }^{1}$

In Teucrium different types of glandular trichomes that produce essential oils were already recognized. ${ }^{2-5}$ The compositions of the volatile oils of some taxa have also been reported in the literature. ${ }^{6-12}$ Nevertheless, regarding T. salviastrum, there are no studies on the morphology and distribution of trichomes and an unique study on its essential oil was reported. ${ }^{13}$

\footnotetext{
* Correspondence to: L. R. Salgueiro, Laboratório de Farmacognosia/CEF, Faculdade de Farmácia, Universidade de Coimbra, Rua do Norte, 3000 Coimbra, Portugal. E-mail: ligia@ff.uc.pt
}

In this paper we report on both the chemical composition of the essential oils obtained from the aerial parts of $T$. salviastrum collected at different vegetative stages and from distinct locations, as well as the micromorphology and the histochemistry of the secretory structures occurring on vegetative and reproductive organs.

\section{Material and Methods}

\section{Plant Material}

Aerial parts of T. salviastrum were collected from different sites in the centre of Portugal. Two collective samples were obtained during the post-flowering period of the plant at Serra do Açor, Pampilhosa da Serra (sample A) and at Serra da Estrela, Fonte de Paulo Martins (sample B). Other representative samples were collected during the flowering period at Serra do Açor, Pampilhosa da Serra (sample C), and Serra da Estrela, Torre (sample D). The leaves (D1) and the flower heads (Df) from the latter sample were studied separately. 
Voucher specimens were deposited in the Herbarium of the Botanical Garden of Coimbra (COI).

\section{Scanning Electron Microscopy (SEM)}

Leaves, stems and flowers at different developmental stages, were fixed with $3 \%$ GA in $0.1 \mathrm{M}$ sodium cacodylate buffer, $\mathrm{pH} 7.0$, for $3 \mathrm{~h}$ at room temperature. The material was rinsed thoroughly in the same buffer, then fixed with a $2 \% \mathrm{OsO}_{4}$ aqueous solution for $1 \mathrm{~h}$ at room temperature. After washing in water, the material was dehydrated in a graded alcohol series and critical point dried in a Polaron E 3500. The dried specimens were sputter-coated with gold then examined with a Jeol JSM T220 scanning electron microscope at $10 \mathrm{kV}$.

\section{Histochemistry}

The histochemical tests were performed using fresh plant material. Total lipids were detected by Nile blue A and unsaturated lipids by $\mathrm{OsO}_{4},{ }^{14,15}$ with appropriate controls carried out simultaneously. The autofluorescence of the secreted material was studied using a Leitz epifluorescence microscope.

\section{Isolation and Essential Oil Analysis}

The essential oils were isolated by water distillation for $3 \mathrm{~h}$ from air-dried plant material and the oil yield determined in accordance with the European Pharmacopoeia method. ${ }^{16}$ The resulting oils were analysed by GC and GC-MS. For GC analyses two fused-silica capillary columns with stationary phases of different polarities where used: SPB-1 (polydimethylsiloxane $30 \mathrm{~m} \times$ $0.20 \mathrm{~mm}$ i.d., film thickness $0.20 \mu \mathrm{m}$ ), and SupelcoWax 10 (polyethyleneglycol $30 \mathrm{~m} \times 0.20 \mathrm{~mm}$ i.d., film thickness $0.20 \mu \mathrm{m})$. Oven temperature program: $70-220^{\circ} \mathrm{C}$ at $3^{\circ} \mathrm{C} / \mathrm{min}$, then $220^{\circ} \mathrm{C}$ for $15 \mathrm{~min}$; injector temperature, $250{ }^{\circ} \mathrm{C}$; (carrier gas, helium, adjusted to a linear velocity of $30 \mathrm{~m} / \mathrm{s}$; split ratio, 1:40; detector temperature, $250{ }^{\circ} \mathrm{C}$.)

$\mathrm{GC}-\mathrm{MS}$ was performed with a HP1 fused silica column (polydimethylsiloxane $30 \mathrm{~m} \times 0.25 \mathrm{~mm}$ i.d., film thickness $0.25 \mu \mathrm{m})$, interfaced with a mass selective detector. GC parameters were as above; interface temperature, $250{ }^{\circ} \mathrm{C}$; MS source temperature, $230^{\circ} \mathrm{C}$; MS quadrupole temperature, $150^{\circ} \mathrm{C}$; ionization energy, 70 $\mathrm{eV}$; ionization current, $60 \mu \mathrm{A}$; scan range, 35-350 u; scans/s 4.51

The oil components were identified by their retention indices, calculated by their linear interpolation relative to the retention times of a series of $n$-alkanes, and by comparison of their mass spectra with those from a home-made library and/or from the literature. ${ }^{17,18}$
To confirm the identity of the major sesquiterpenes, the essential oils were analysed using ${ }^{13} \mathrm{C}-\mathrm{NMR}$ without previous separation of components, according to an experimental procedure and a computerized method previously described. ${ }^{19}{ }^{13} \mathrm{C}$-NMR spectra were recorded at $50 \mathrm{MHz}$ in $\mathrm{CDCl}_{3}$, using TMS as internal standard. The sesquiterpenes were identified by comparison of the values of the carbon chemical shifts in the mixture spectrum with those of reference spectra compiled in a computerized data bank.

Relative amounts of individual components were calculated based on GC peak areas without FID response correction factor.

\section{Results and Discussion}

The aerial parts of $T$. salviastrum are covered by an indumentum containing both non-glandular and glandular trichomes (Figure 1). The non-glandular trichomes are needle-shaped and have a cuticle with papillae. The glandular ones are of two types: peltate trichomes, occurring only on the abaxial surface of the leaves (Figure 2 arrows) and consisting of a basal epidermal cell, a very short stalk cell and a multicellular head covered by a thick cuticle; and capitate trichomes, consisting of a basal epidermal cell, a multicellular stalk with 2-4 long cells and a rounded glandular head cell. Capitate trichomes, which are much more abundant than the peltate ones, occur on both leaf surfaces (Figures 2-5). These trichomes have been described for other Teucrium spp. ${ }^{20-22}$ and for other Lamiaceae. ${ }^{23,24}$

Both reproductive and vegetative organs show the same types of glandular trichomes (Figures 6, 7). The indumentum is very dense on the calyx and the capitate trichomes possess a long multicellular stalk (Figure 6). On the upper surface of the four-lobed ovary, the peltate

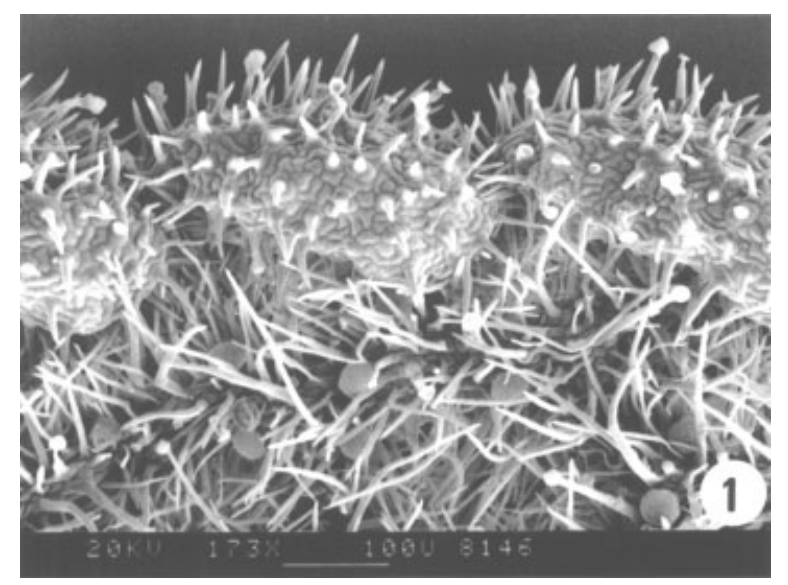

Figure 1. Abaxial and adaxial surface of a young leaf of $T$. salviastrum showing peltate and capitate glandular trichomes and non-glandular ones 


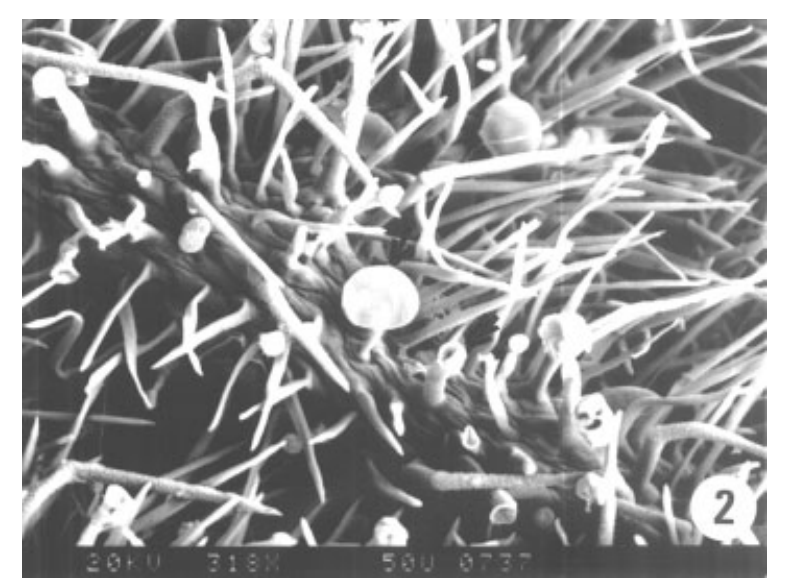

Figure 2. Leaf abaxial surface of $T$. salviastrum showing peltate (arrow) and capitate (double arrow) trichomes

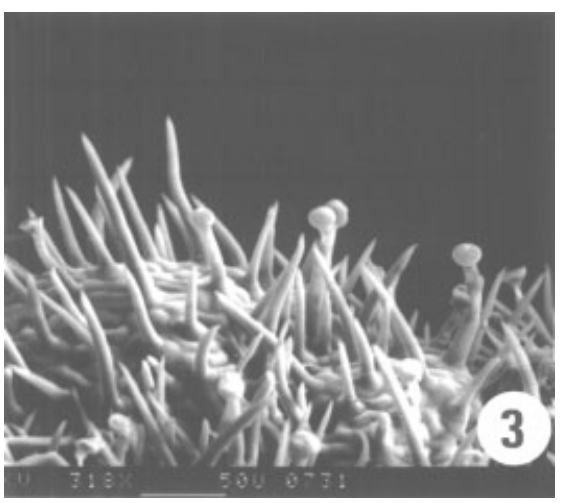

Figure 3. Leaf adaxial surface of $T$. salviastrum showing only one type of glandular trichomes (capitate)

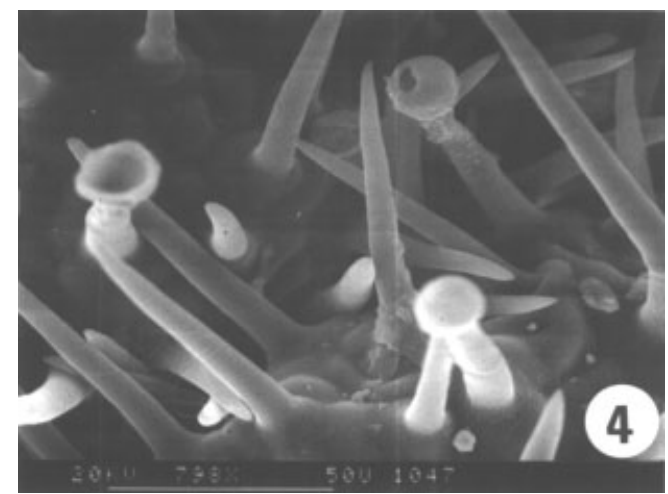

Figure 4. Different stages of secretion release from glandular trichomes of $T$. salviastrum

trichomes are sparsely distributed. Although the glandular trichomes have been observed on the ovary of other Lamiaceae spp. such as Cedronella canariensis (Antunes T, Pinto I, unpublished results) and Leonotis leonurus ${ }^{25}$ this is the first time they have been recorded as being present on the ovary of a Teucrium sp. In this study we are giving most emphasis to the capitate

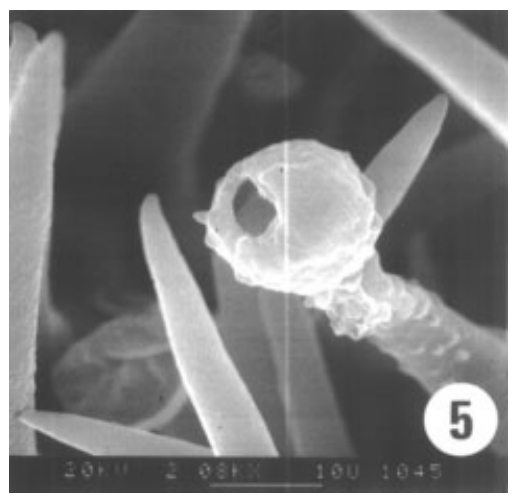

Figure 5. Detail of Figure 4, showing the release of secretion of $T$. salviastrum

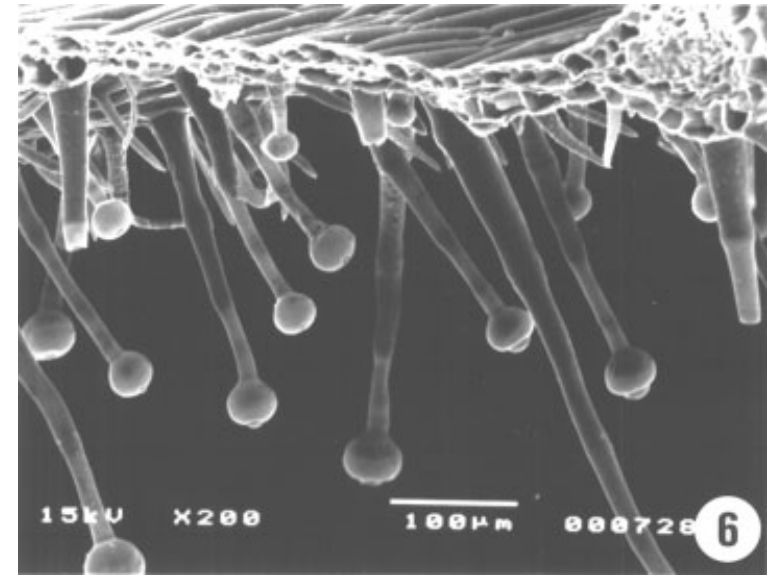

Figure 6. Transverse section of the calyx of $T$. salviastrum showing long glandular trichomes on the outer surface

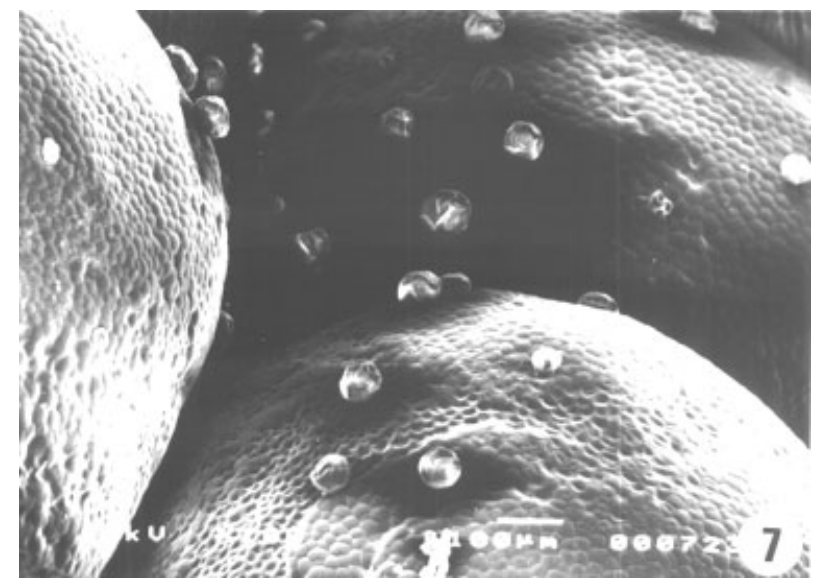

Figure 7. View of peltate trichomes of $T$. salviastrum, sparsely distributed on the four-lobed ovary

trichomes (Figures 4, 6), due to their abundance, and also because of particular aspects related to the secreted material release process. The cuticle of some trichomes appear slightly protruding, due to the high amount of secretion held in the subcuticular space. The pressure 


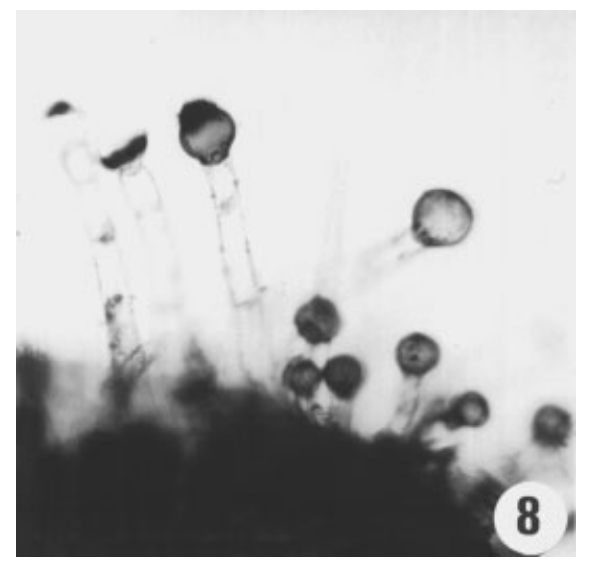

Figure 8. The secreted material stained blue with Nile blue

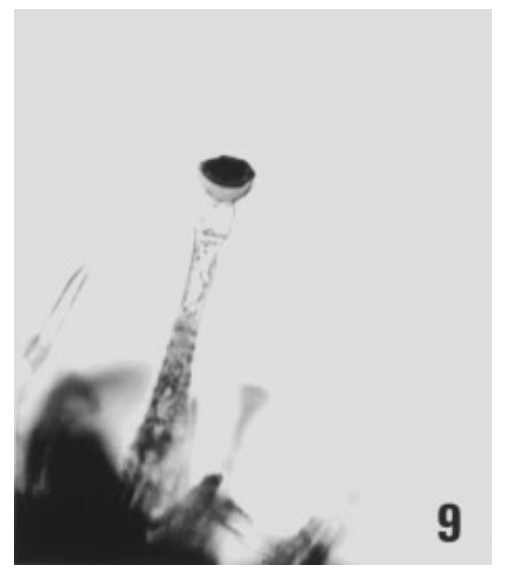

Figure 9. Osmium tetroxide stains the secreted material dark. Note the cup-shaped trichomes

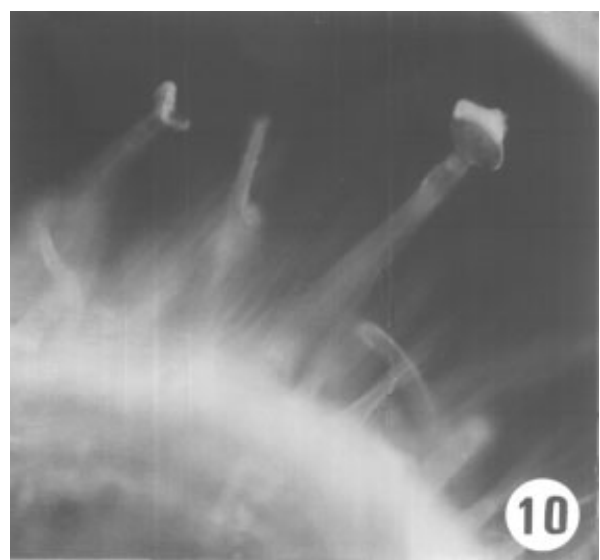

Figure 10. The secreted material showed gold-yellow fluorescence under blue light

resulting from the accumulation of this material causes the cuticle rupture, giving rise to the frequently observed circular holes on the top of the head cells (Figure 4). After cuticule rupture, the glandular head cell assumes
Table 1. Percentage composition of the essential oils isolated from $T$. salviastrum

\begin{tabular}{|c|c|c|c|c|c|c|}
\hline \multirow[t]{2}{*}{$\mathrm{RI}^{\mathrm{a}}$} & \multirow[t]{2}{*}{ Compound } & \multicolumn{5}{|c|}{ Calculate (\%) } \\
\hline & & $A$ & B & C & $\mathrm{DI}$ & Df \\
\hline 930 & $\alpha$-Pinene & 0.1 & 0.2 & $\mathrm{t}$ & $\mathrm{t}$ & $\mathrm{t}$ \\
\hline 959 & Oct-1-en-3-ol & 1.8 & 1.5 & 0.5 & 0.7 & 0.8 \\
\hline 964 & Sabinene & 0.6 & 0.6 & 0.2 & 0.2 & 0.2 \\
\hline 969 & $\beta$-Pinene & $\mathrm{t}$ & $\mathrm{t}$ & $\mathrm{t}$ & $\mathrm{t}$ & $\mathrm{t}$ \\
\hline 980 & $\beta$-Myrcene & 0.5 & 0.5 & 0.2 & 0.5 & 0.2 \\
\hline 1012 & $\alpha$-Terpinene & 0.1 & 0.1 & $\mathrm{t}$ & $\mathrm{t}$ & $\mathrm{t}$ \\
\hline 1012 & $p$-Cymene & 0.1 & 0.1 & $\mathrm{t}$ & $\mathrm{t}$ & $\mathrm{t}$ \\
\hline 1020 & Limonene & 1.4 & 1.6 & 0.8 & 0.9 & 0.7 \\
\hline 1025 & $Z$ - $\beta$-Ocimene & 4.6 & 4.5 & 4.3 & 2.6 & 2.1 \\
\hline 1035 & $E$ - $\beta$-Ocimene & 0.6 & 0.5 & 0.5 & 0.3 & 0.3 \\
\hline 1047 & $\gamma$-Terpinene & 0.1 & 0.1 & 0.1 & 0.2 & 0.1 \\
\hline 1051 & $n$-Octanol & 0.1 & $\mathrm{t}$ & & & \\
\hline 1071 & Dimethylstyrene & & $\mathrm{t}$ & $\mathrm{t}$ & & \\
\hline 1077 & Terpinolene & 0.8 & 0.9 & 0.6 & 0.7 & 0.6 \\
\hline 1083 & Linalol & 1.0 & 0.6 & 0.4 & 0.4 & 0.7 \\
\hline 1117 & allo-Ocimene & 0.1 & 0.1 & 0.2 & & $\mathrm{t}$ \\
\hline 1158 & Terpineol-4 & 0.3 & 0.8 & 1.1 & 0.2 & 0.2 \\
\hline 1169 & $\alpha$-Terpineol & 0.1 & 0.1 & 0.1 & 0.1 & 0.1 \\
\hline 1212 & Geranial & 0.1 & & & & \\
\hline 1235 & Dec-3-ene-1-ol & & 0.1 & & & \\
\hline 1240 & Neral & 0.2 & & & & \\
\hline 1264 & Bornyl acetate & 0.1 & & & & \\
\hline 1325 & Eugenol & & $\mathrm{t}$ & 0.1 & $\mathrm{t}$ & $\mathrm{t}$ \\
\hline 1326 & Piperitenone oxyde & 0.3 & & & & \\
\hline 1343 & $\alpha$-Cubebene & 0.1 & 0.1 & 0.1 & $\mathrm{t}$ & $\mathrm{t}$ \\
\hline 1357 & $E$ - $\beta$-Damascenone & 0.2 & 0.3 & 0.4 & 0.3 & 0.2 \\
\hline 1359 & Decanoic acid & & $\mathrm{t}$ & $\mathrm{t}$ & & \\
\hline 1364 & $\alpha$-Ylangene & 0.1 & 0.1 & & $\mathrm{t}$ & $\mathrm{t}$ \\
\hline 1368 & $\alpha$-Copaene & 0.3 & 0.2 & 0.2 & 0.3 & 0.3 \\
\hline 1375 & $\beta$-Bourbunene & 1.2 & 0.8 & 0.9 & 0.7 & 1.1 \\
\hline 1378 & $\beta$-Cubebene & 0.2 & 0.2 & & $\mathrm{t}$ & $\mathrm{t}$ \\
\hline 1396 & Z-Caryophyllene & 0.1 & 0.1 & $\mathrm{t}$ & $\mathrm{t}$ & 0.1 \\
\hline 1404 & $\alpha$-Gurjunene & & 0.3 & & & \\
\hline 1409 & $E$-Caryophyllene & 19.1 & 20.5 & 26.6 & 21.8 & 24.1 \\
\hline 1428 & Aromadendrene & & & 0.2 & & \\
\hline 1440 & $\alpha$-Humulene & 3.1 & 3.3 & 4.1 & 3.5 & 3.8 \\
\hline 1447 & $E$ - $\beta$-Farnesene & 27.6 & 29.3 & 25.8 & 26.1 & 26.9 \\
\hline 1464 & $\gamma$-Muurolene & 0.8 & & & & \\
\hline 1467 & Germacrene-D & 15.8 & 13.7 & 14.9 & 21.0 & 21.6 \\
\hline 1472 & $\beta$-Selinene & 0.2 & & & & \\
\hline 1481 & Bicyclogermacrene & 1.9 & 1.3 & 2.8 & 2.8 & 2.7 \\
\hline 1486 & $\alpha$-Muurolene & 0.4 & 0.3 & & 0.8 & 0.6 \\
\hline 1496 & $\gamma$-Cadinene & 0.2 & 0.2 & 2.6 & 0.6 & 0.3 \\
\hline 1501 & Z-Calamelene & 0.1 & 0.1 & 0.1 & & \\
\hline 1507 & $\beta$-Bisabolene & 1.4 & 1.5 & & 1.5 & 1.6 \\
\hline 1507 & $\delta$-Cadinene & 1.6 & 1.0 & 1.6 & 2.5 & 1.9 \\
\hline 1515 & Cadina-1,4-diene & 0.1 & $\mathrm{t}$ & 0.1 & & \\
\hline 1528 & Elemol & 0.3 & & & & \\
\hline 1531 & $\alpha$-Bisabolene & 0.1 & 0.1 & & - & 0.2 \\
\hline 1539 & Germacrene B & & 0.1 & & & \\
\hline 1544 & $E$-Nerolidol & 0.8 & 0.7 & 0.6 & 0.6 & 0.7 \\
\hline 1552 & Spathulenol & 0.6 & 0.7 & 0.4 & 0.4 & \\
\hline 1557 & Caryophyllene oxide & 2.7 & 3.6 & 2.5 & 1.4 & 2.0 \\
\hline 1561 & Globulol & 0.1 & 0.1 & & 0.2 & \\
\hline 1568 & Viridiflorol & 0.1 & 0.2 & & 0.4 & 0.4 \\
\hline 1580 & Humulene oxide & 0.6 & 0.7 & 0.5 & $\mathrm{t}$ & 0.7 \\
\hline 1607 & $\gamma$-Eudesmol & 0.1 & & 0.5 & & \\
\hline 1610 & Isospathulenol & & & & & 0.3 \\
\hline 1619 & T-Cadinol & 0.3 & 0.6 & 0.6 & 1.7 & 1.0 \\
\hline 1627 & $\alpha$-Cadinol & 0.3 & 0.3 & 0.3 & 1.5 & 0.8 \\
\hline 1627 & T-Muurorol & 0.4 & 0.4 & 0.5 & 0.8 & 0.4 \\
\hline 1828 & Hexahydrofarnesyl acetone & & & & & 0.2 \\
\hline 2017 & Abietatriene & & 0.1 & 0.5 & & \\
\hline 2096 & Phytol & 0.2 & 0.1 & & 0.2 & 0.2 \\
\hline
\end{tabular}


Table 1. (Continued)

\begin{tabular}{lrrrrr}
\hline $\mathrm{RI}^{\mathrm{a}}$ Compound & \multicolumn{5}{c}{ Calculate (\%) } \\
\cline { 2 - 6 } & $\mathrm{A}$ & $\mathrm{B}$ & $\mathrm{C}$ & $\mathrm{Dl}$ & $\mathrm{Df}$ \\
\hline Total identified & 94.0 & 93.3 & 95.9 & 95.9 & 97.9 \\
Monoterpene hydrocarbons & 8.9 & 9.3 & 6.9 & 5.4 & 4.1 \\
Oxygen containing monoterpenes & 2.0 & 1.6 & 2.1 & 0.7 & 1.0 \\
Sesquiterpene hydrocarbons & 74.7 & 73.4 & 80.0 & 81.9 & 85.5 \\
Oxygen containing sesquiterpenes & 6.4 & 7.1 & 5.9 & 7.0 & 6.4 \\
Others & 2.0 & 1.9 & 1.0 & 0.9 & 0.9 \\
\hline
\end{tabular}

a Relative to $\mathrm{C}_{9}-\mathrm{C}_{21} n$-alkanes on the SPB-1 column.

$\mathrm{t}$, trace $(<0.05 \%)$.

Post-flowering period samples: A, Pampilhosa da Serra; B, Serra da Estrela/ Fonte de Paulo Martins.

Flowering period samples: C, Pampilhosa da Serra; Dl (leaves), Df (flowers), Serra da Estrela/Torre.

a cup shape and appears to be covered with the remnants of the secretion material (Figure 5). The process of secretion release just described has been reported for other species of Lamiaceae possessing similar types of trichomes. ${ }^{23}$

During the active stage of secretion, the sub-cuticular space appeared filled with secretion material. In handsectioned fresh plant material, the secretion showed affinity to Nile blue (Figure 8) and osmium tetroxide reagents (Figure 9), revealing its lipophilic nature, as well as autofluorescencing under UV $(340-380 \mathrm{~nm})$ and bluelight (450-490 nm) (Figure 10).

The essential oils, isolated by water distillation, were yellowish in colour, with a yield of $0.1-0.2 \%$ (v/w); 42-44 components were identified in the five oil samples, which represented $93-98 \%$ of the total oil (Table 1).

The monoterpenic fraction represented only 5.1$10.9 \%$ of the total oil, $Z$ - $\beta$-ocimene $(2.1-4.6 \%)$ and limonene $(0.7-1.6 \%)$ being the major compounds.

Sesquiterpene hydrocarbons made up the bulk in all the samples, representing $73.4-85.5 \%$ of the total oil. $E$ - $\beta$-Farnesene (25.8-29.3\%), E-caryophyllene (19.1-26.6\%) and germacrene D (13.7-21.6\%) were the major compounds identified. Oxygen-containing sesquiterpenes also represented an important fraction, at $5.9-7.1 \%$ of the total oil, being dominated by caryophyllene oxide (1.4-3.6\%).

The oils isolated from leaves collected during both the flowering and post-flowering phases of the plant, and that obtained from the flower heads, exhibited a quite similar chemical composition. This can be related, to some extent, to the same glandular trichomes being observed in both the vegetative and reproductive organs.

The compositions of these essential oils are remarkably different from those reported in the literature. ${ }^{13}$ For a sample of the same species, with the same origin of our samples B and D from Serra da Estrela, the authors reported aristolene $+\beta$-caryophyllene
(21.60\%), $\alpha$-humulene + allo-aromadendrene $(18.99 \%)$ and caryophyllene epoxide + spathulenol $(18.60 \%)$ as the major components. They did not report $E-\beta$ farnesene, the main compound in all our oil samples $(25.8-29.3 \%)$, whose identity could be confirmed by ${ }^{13} \mathrm{C}-\mathrm{NMR}$. On the other hand, aristolene and alloaromadendrene were not detected in our oil samples. Moreover, $\alpha$-humulene, caryophyllene oxide, and spathulenol were only detected in relatively small amounts. In our samples, apart from $E$ - $\beta$-farnesene, only $E$-caryophyllene and germacrene D attained a concentration higher than $10 \%$.

Acknowledgements - We thank Professor Joseph Casanova and Professor Felix Tomi (University of Corsica) for providing ${ }^{13} \mathrm{C}$-NMR spectra.

\section{References}

1. Devesa JA. In Flora Vasc Andalucia Occidental, No. 2, Teucrium, Valdés B, Talavera S, Fernandéz-Galiano E (eds). Ketres: Barcelona, 1987; 458-469.

2. Antunes T, Sevinate-Pinto I, Figueiredo AC et al. Acta Bot Gallica 1997; 144: 363-369.

3. Servettaz O, Bini Maleci L, Pinetti A. Plant Syst. Evol. 1992; 179: 129-139.

4. Servettaz O, Pinetti A, Bellesia F, Bini Maleci L. Bot. Acta 1994; 107: 369-472.

5. Sevinate-Pinto I, Antunes T. Flora 1991; 185: 207-213.

6. Cakir A, Duru M, Harmandar M, Ciriminna R, Passannanti S. J. Essent. Oil Res. 1998; 10: 113-115.

7. Pérez-Alonso MJ, Velasco-Negueruela A, López-Sáez JA. J. Essent. Oil Res. 1993; 5: 397-402.

8. Barroso JG, Pedro LG, Figueiredo AC, Antunes T, SevinatePinto I, Scheffer JJC. Flavour Fragr. J. 1993; 8: 277-280.

9. Barroso JG, Figueiredo AC, Pedro LG et al. Flavour Fragr. J. 1996; 11: 129-132.

10. Baser KHC, Demircakmak B, Duman H. J. Essent. Oil Res. 1997; 9: $545-549$.

11. Baser KHC, Demirci B, Duman H, Aytaç Z. J. Essent. Oil Res. 1999; 11: 61-62.

12. Velasco-Negueruela A, Pérez-Alonso MJ, Palá-Paul J, RamosVásquez P, Paz P, Garcia Vallejo NC. J. Essent. Oil Res. 1999; 11: $553-555$.

13. Velasco-Negueruela A, Pérez-Alonso MJ. Phytochemistry 1990; 29: $1165-1169$.

14. Cain AJ. Qu. J. Micr. Sci. 1947; 88: 383-392.

15. Ganter P, Jolles G. Histochimie Normal et Pathologique, vol I, 2nd edn. Gauthier-Villars: Paris, 1969.

16. Council of Europe. European Pharmacopoeia, 3rd edn. EC: Strasbourg, 1997; 121-122.

17. Adams RP. Identification of Essential Oil Components by Gas Chromatography-Mass Spectroscopy. Allured: Carol Stream, IL; 1995.

18. Joulain D, König WA. The Atlas of Spectral Data of Sesquiterpene Hydrocarbons. E.B. Verlag: Hamburg, 1998.

19. Salgueiro LR, Vila R, Tomás X et al. Phytochemistry. 1995; 38: 391-396.

20. Antunes T, Sevinate-Pinto I, Barroso JG et al. Bol. Museu Mun. Funchal (História Natural) 1995; 4: 21-27.

21. Antunes T, Sevinate-Pinto I, Figueiredo AC et al. Acta Bot. Gallica 1997; 144: 363-369.

22. Bini Maleci L, Servettaz O. Plant Systemat. Evolut. 1991; 174: 83-91.

23. Werker E, Ravid U, Putievsky E. Israel J. Bot. 1985; 34: 31-45.

24. Werker E. Flavour Fragr. J. 1993; 8: 249-255.

25. Ascensão L, Marques N, Pais MS. Ann Bot. 1995; 75: 619-626. 